\title{
Kent Kimliğinin oluşumunda Kutsal Merkezin Yeri: Islam Dönemi Kudüs'ünde Harem-i şerif Örneği
}

Yrd. Doç. Dr. Kayahan Türkantoz.

MSGSÜ Mimarlık Fakültesi, Bina Bilgisi Anabilim Dalı

İbranîce adı "Yaruşalayim" olan Kudüs'te kent kimliğinin en önemli bileşkesi "kutsallık”tır. Kentin Arapça adı olan "elKuds" bile "kutsal" anlamına gelir. M.Ö.1000 civarından Hz. İsa'nın ölümüne (M.S.32) kadar Museviliğin (Dan 1996, 6078), bu tarihten İslâm'ın doğuşuna (M.S. VII. yüzyıl başı) kadar Museviliğin yanı sıra Hıristiyanlığın (Fredriksen 1996), bundan günümüze kadar da İslâm'la birlikte (Neuwirth 1996; Hasson 1996,349-385), tek tanrı üç dinin ortak kutsal kenti olmuştur. İslâm terminolojisinde "Harem-i Şerif" ya da kısaca "Harem" olarak anılan kutsal alan ise en az 3000 yıldır bu özelliğini korumuştur.

\section{Kentin Topografyası ve Harem-i Şerif'in Konumu}

Harem-i Şerif'in konumunu tanıtırken Kudüs'ün kendine özgü topografyasını bir bütün olarak ele almak zorunludur. Engebeli bir arazi yapısına sahip olan Kudüs, kuzeye doğru gittikçe yükselen ve genişleyen bir platonun güney kenarında kurulmuştur. Yüzeyi dalgalı olan platonun çevresini kuşatan alçak arazi, vadiler şeklinde kısmen kent içine uzanır.
Eski kentin ve yakın çevresinin, birbirini izleyen tepeler ve bunların arasındaki vadiler dizisinden oluşan topografyası şu şekilde özetlenebilir: (Buhl 1940, 952; Bahat 1976, 4-5; Burgoyne 1987, 40-41; Bahat 1996, 38100) (Şekil 1).

Surların kuşattığı alanın kuzeydoğu köşesini, kuzeybatı-güneydoğu doğrultusunda uzanan Beth Zetha Sırtı ile bunun yanında uzanan ve aynı adı taşıyan vadi işgal eder. Söz konusu vadinin batısında, aynı doğrultuda gelişen Antonia Sırtı güneye doğru Tapınak Tepesi (Moriah Tepesi) ile devam eder. Adından da anlaşılacağı gibi bu tepede, bir zamanlar ünlü Süleyman Tapınă̆ı'nı, VII. yüzyılın başından bu yana da, Kubbet el-Sahra ile Mescid el-Aksa'yı barındıran kutsal alan (Harem-i Şerif) yer almaktadır. Tapınak Tepesi'nin bitiminde, yükselti yön değiştirerek güneye doğru ilerler ve Ofel Tepesi ile noktalanır. M.Ö. 538'de son bulan I. Tapınak Döneminde, "Davud Kenti” olarak anılan ilk yerleşimin bulunduğu Ofel Tepesi'nin doğusunda, kuzeygüney doğrultusunda Kidron (Kedron) Vadisi uzanır. Kuzey kesiminde Beth
Üç tektanrılı dinin ortak kutsal kenti olan Kudüs'te, 3000 yıldır kutsal merkez olarak varlığını sürdüren, İslâm döneminde de "Haremi Şerif" adını almış olan bölge, kentin sahip olduğu zengin dinsel-simgesel anlam düzleminin ve bu düzleme yansıyan "kutsal geometrisinin" odak noktasıdır. Harem-i Şerif' in kent kimliğinin oluşumundaki yeri incelendiğinde, söz konusu kutsal alanın, eski kentin yaklaşık 1/5' ini kaplayarak iki boyutta (planda) egemen olduğu gözlenir. Diğer taraftan, Harem-i Şerif' in merkezinde yer alan ve kentteki en görkemli İslâm yapısı olan Kubbet el-Sahra, çevrenin en yüksek tepelerinden biri üzerinde yükselmesi, merkezî planlı kitlesini taçlandıran kasnağı ve soğan kubbesiyle, kente üçüncü boyutta (siluette) egemen olan güçlü bir görsel odak teșkil eder. Bir zamanlar, Süleyman Tapınağı'nın yükseldiği platformda VII. yüzyıl sonlarında Emevîler tarafından yaptırılan Kubbet

el-Sahra, zaman içinde söz konusu tapınakla özdeşleşerek dördüncü boyutta ve toplumsal bellekte de Kudüs'un "simgesi” haline gelmiştir, giderek kentin "amblemi" olarak tanımlanmaya başlamış ve günümüzde "turistik objeye" dönüşmüştür. Ancak, bu dönüşümünün Kubbet el-Sahra'nın, Kudüs'ü “simgelediği” gerçeğini ortadan kaldırmadığı, bilakis güçlendirdiği ileri sürülebilir. summary:

In Jerusalem, the common holy city of the three monotheistic religions, the area which survived for 3000 years as the sacred centre, and known as "Haram al-Sharif" during the Islamic period, is the focus of the town's rich religious-symbolic background, and of the "holy geometry" reflected on it. If we study the place of the

Haram al-Sharif in the formation of the urban identity, we notice that this sacred area, by occupying almost the 1/5 of the old town surface, is dominant in two dimensions (on the plan). On the other hand, the Dome of the Rock, located at the centre of Haram al-Sharif and being the most splendid Islamic building in town, constitutes a strong visual focus that dominates the holy city in the 3rd dimension (silhouette) as well, by rising on one of the highest hills of the surrounding, and with its central mass crowned by an onion-shaped dome resting on a high drum. This monument, built in the 7th century by the Umayyades at the site of the Temple of Solomon, was identified for centuries with its mythical predecessor and so became the "symbol" of Jerusalem in the 4th dimension (time) and in the collective memory. With time, this symbol was metamorphosed into an emblem and nowadays into an artefact of tourism. However, we can assert that this transformation, instead of denying, supports the fact that the Dome of the Rock "symbolises" Jerusalem. Anahtar kelimeler: Kutsal merkez, kent kimliği, görsel odak, toplumsal bellek, simge. Keywords:

Sacred centre, urban identity, visual focus, collective memory, symbol.

60 Sayı 4, Mayıs 2006 


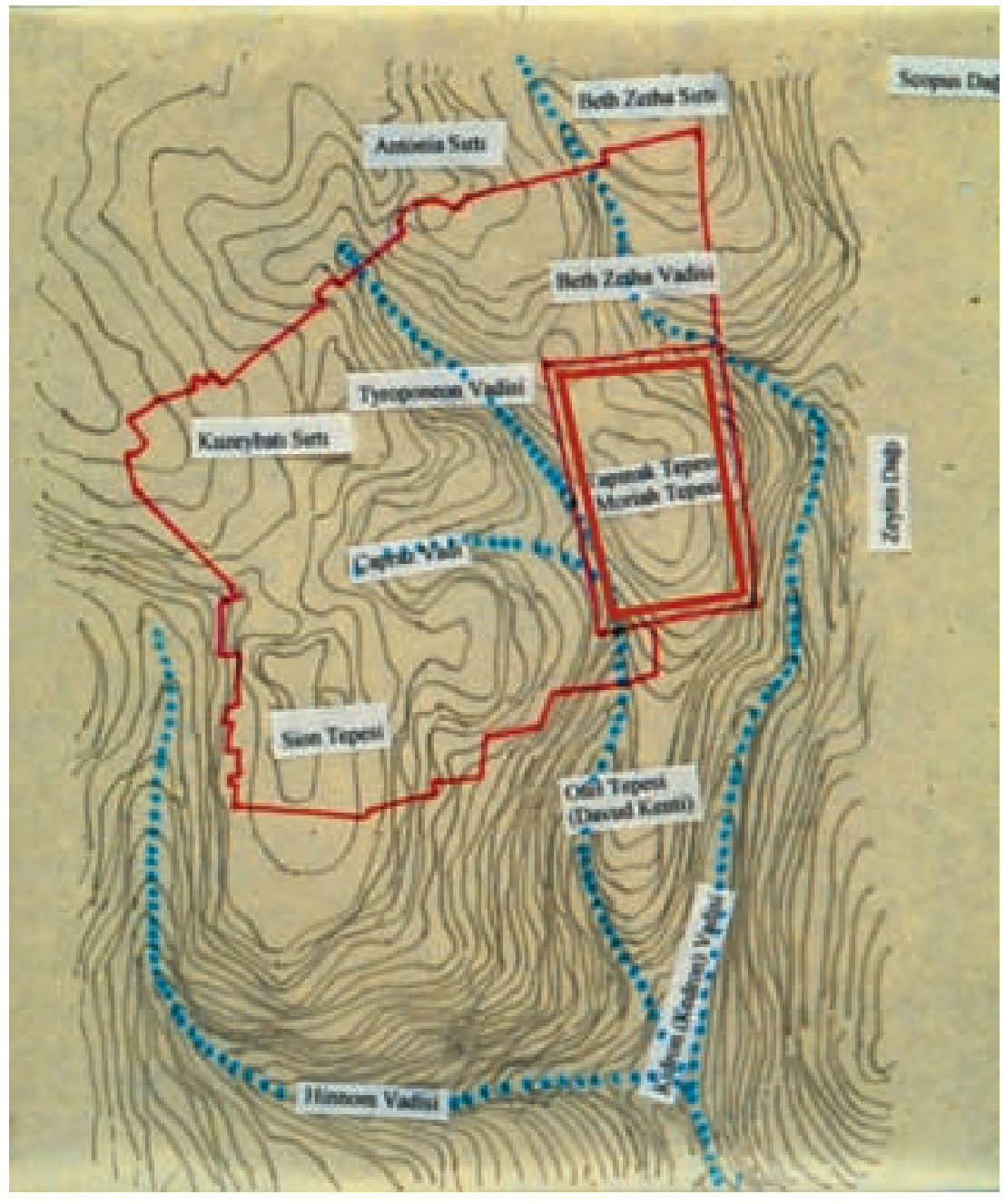

Şekil: I

Kudüs ve yakın feuresinin topografyası

(Türkantoz, K.)
Zetha Vadisi'nin birleştiği Kidron

Vadisi'nin gerisinde (doğusunda) ise ünlü Zeytin Dağı, bunun kuzeyinde de Scopus Dağı yükselmektedir.

Birbirine eklemlenen "Antonia Sirtı Tapınak Tepesi - Ofel Tepesi” zincirinin doğusundaki Tyroponeon Vadisi kentin tarihî topografyasında önemli bir yere sahiptir. Kudüs'ü kuzey-güney doğrultusunda kat eden bu vadi kenti, eşit olmayan -doğudaki daha büyük olan- iki parçaya ayırır. M.Ö. VI. yüzyıldan bu yana, kentin en uzun ömürlü ulaşım eksenini (günümüzde de El-Vad Sokă̆ı'nı) barındıran Tyroponeon Vadisi'nin batısında, Kuzeybatı Sırtı,
Çapraz Vadi, Sion Tepesi ve Hinnom Vadisi birbirini izler. Çapraz Vadi, batıdan doğuya uzanarak Tyroponeon Vadisi'ne saplanmaktadır. Surların güneyinde, Tyroponeon, Kidron ve Hinnom vadileri birbirlerine kavuşurlar.

Kudüs'te topografyayı ve kutsallık odaklarının bu topografya üzerindeki dağılımını, kentin sahip olduğu zengin dinsel-simgesel anlam düzleminden ve bu düzleme yansiyan "kutsal geometrisinden" (Kühnel 1996, 288-332) ayrı düşünmek imkânsızdır. Örneğin, Musevîlerin ve Hıristiyanların yanı sıra, yöre Müslümanlarının çoğunluğunca da paylaşılan inanca göre, kıyamet günü Mesih kentin doğusundaki Zeytin Dağı'na inecek ve Harem-i Şerif'in bu yöne bakan kapısından (günümüzde örülmüş olan Altın Kapı'dan) kutsal alana dahil olacaktır. Yöre Müslümanları bu inanç doğrultusunda Kidron Vadisi'nin kıyametteki cehennemi temsil ettiğini kabul ederler. Bu nedenle "Vadi el-Cehennem" adını verdikleri bu vadinin üzerine Sırat Köprüsü’nün kurulacağına, Mesih'e uyarak bu köprüden geçen "salih kulların" cennetin timsali olan Harem-i Şerif'e gireceklerine, günahkâr ve asi kulların köprüden cehenneme yuvarlanacaklarına inanırlar. Nitekim Altın Kapı'nın Müslümanlar arasındaki adı "Rahmet Kapıs1" anlamına gelen "Bâb el-Rahme"dir.

\section{Harem-i Şerif'in Oluşumu ve Tarihsel Sürekliliği}

Kuruluşundan beri duvarlarla kuşatılmış olan Harem-i Şerif'in konumu, Davud Peygamber'in Kudüs'ü fethettiğ M.Ö.1000 civarından beri değişmemiştir. Davud'un oğlu Süleyman Peygamber, Harem-i Şerif'in merkezindeki kutsal kayanın çevresine, kaynaklarda 
"Süleyman Tapınağı” veya "I. Tapınak" olarak geçen anıtsal binayı yaptırmıştır. Süleyman Peygamber'in ölümünden sonra devlet, kuzeyde İsrail Krallığı, güneyde Yahudiye (Judea) Krallığı olmak üzere ikiye ayrıldı. Yahudiye Krallı̆̆g'nın başkenti olan Kudüs, eski siyasi ve ekonomik gücünü artık yitirse de, İsaiah ve Jeremiah gibi güçlü liderler sayesinde ruhani üstünlüğünü korumakta, Tapınak ile çevresindeki kutsal alan görkemini sürdürmekteydi (Sharon 1973, 16).

M.Ö. 586'da yöreyi topraklarına katan Babil İmparatoru Nebukadnezzar, Tapınak da dahil olmak üzere Kudüs'ü yerle bir ederek bütün halkını kendi başkentine sürdü ve böylece I. Tapınak Dönemi (M.Ö.1000-586) sona erdi. Yaklaşık 50 yıl sonra Pers İmparatoru Kirus'un Babil'i zaptetmesiyle anayurtlarına kavuşan Yahudiler, Kudüs'te M.Ö. 515'te Tapınağı yeniden inşa ettiler. II. Tapınak Dönemi’ne (M.Ö.515-M.S.70) adını veren bu yapının "Zorababel

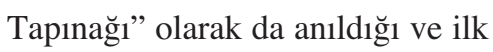
tapınaktan daha büyük olduğu tahmin edilmektedir.

Kudüs, Pers egemenliğine (M.Ö.537-332) son veren Büyük İskender'den sonra, Helenistik Dönem'de, kutsal merkezin ve onun yönetiminden sorumlu olan baş rahiplerin kent hayatı üzerindeki nüfuzları devam etti. M.Ö.167-63 arasında Kudüs'e egemen olan Hasmonlar hanedanı Tapınak'ta ve çevresindeki kutsal alanda onarımlar gerçekleştirdi. M.Ö.63'te Kudüs'ü topraklarına katan Romalılara bağlı olarak Yahudiye (Judea) Krallığı'nın tahtına geçen Büyük Herod (M.Ö.37-4) Süleyman Tapınağı'nı, Roma üslubunda yeniden inşa ettirdi. Söz konusu yapı "Herod Tapınağı" olarak da bilinir.
M.S. 70’de I. Yahudi İsyanı'nı bastıran İmparator Titus'un Süleyman Tapınağı'nı ve çevresindeki yapıları yıktırmasına rağmen, kutsal alan varlığını sürdürür. M.S. 136'da, II. Yahudi İsyanı'nın da bastırılmasından sonra, İmparator Hadrianus Kudüs'ü, "Aelia Capitolina”

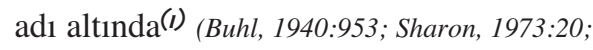
The New Encyclopedia..., 1993, 758) yeniden kurduğunda, kente kazandırmak istediğ $i$ Yunan-Roma kimliğini vurgulamak amacıyla, "Quadra" adını alan kutsal alanın merkezine bir Jüpiter Tapınağı inşa ettirir. Bunun doğu yönüne de, at üzerinde kendi heykelini diktirir (Sharon 1973, 20;

Bahat 1976, 20-21).

M.S. IV. yüzyılın sonlarında

Hıristiyanlığın tek yasal din haline gelmesiyle Quadra'daki Jüpiter Tapınağı'nın faaliyeti de son bulur. Bizans Dönemi'nde kentin dinsel merkezi, Büyük Constantinus'un yaptırdığı, Hz. İsa'nın çarmıha gerildiği mevkide (Golgotha Tepesi'nde) yer aldığına inanılan Kutsal Mezar Kilisesi'ne kaymış, bunun yanı sıra Kutsal Sion Kilisesi, Nea Panaghia Theotokos (Yeni Tanrı Anası Meryem) Kilisesi gibi anıtsal dinî yapılar inşa edilmiş (Buhl 1940, 954-955; Sharon 1973, 21-22; Bahat 1976, 25-27; Burgoyne 1987, 44-45; The New Encyclopedia..., 768-785), içinde harabeler barındıran Harem-i Şerif ise terk edilmiştir (Buhl 1940, 954; Sharon 1973, 22; Bahat 1976, 28; Burgoyne 1987, 44; The New Encyclopedia..., 768).

Hz. Ömer'in hilafeti (634-644) sırasında, 637'de Kudüs'ün İslâm egemenliği altına girmesiyle Harem-i Şerif'in yıldızı yeniden parlar (Gil 1996, 1-37). Hz. Ömer kutsal alanın güney sınırına Mescid elAksâ'yı inşa ettirir. Dört Halife dönemini izleyen Emevî döneminde de, Halife Abdülmelik 691/92'de, Harem-i Şerif'in merkezinde, Hz. Muhammed'in Mi'rac'a

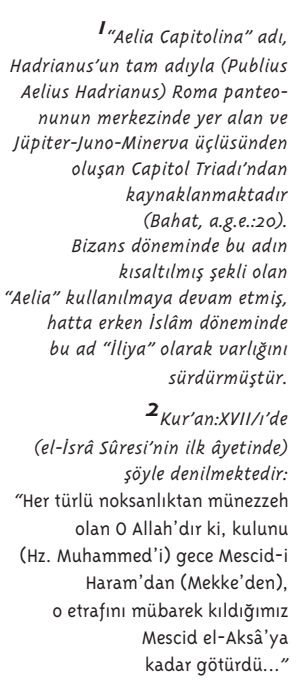

62 Sayı 4, Mayıs 2006 
3 Emevî hanedanının kurucusu Muaviye'nin, saltanatını Kudüs'te ilan etmesi bu bakımdan f̧ok dikkat çekicidir.

${ }^{4}$ Abdülmelik, suriyeli hacıların gönül rizasiyla ya da zorla lbn Zübeyr'e katılmalarından çekindiği için, Mekke'ye gitmelerini

yasakladı. Mekke'ye gitmenin farz olduğu kendisine söylenince de ünlü hadis bilgini el-Zuhrî'yi tanik göstererek, Mekke yerine Kudüs'te bulunan ve $\mathrm{Hz}$.

Muhamed'in Mi'rac'a çıkarken ayağııı üzerine bastı̆̆ına inanılan kutsal taşı ziyaret etmelerini tavsiye etti. Bu olayin ardindan kutsal taşın çeuresinde tavaf galerileri bulunan kubbet elsahra'yı inşa ettirdi.

5 Süryanice bir kaynakta, 660 yılında, Kudüs'te bazı Araplar çeuresinde toplanarak kendisini hükümdar yapmak istediklerinde, Muaviye'nin Kutsal Mezar Kilisesi'ne ve Hz. Meryem'in, Hinnom Vadisi'ndeki mezarina giderek dua ettiğ̈in belirtmektedir. çıktı̆̆ına inanılan kutsal kayanın(2) üzerine, İslâm mimarisinin ilk anıtsal yapısı olan, Kubbet el-Sahra adındaki ziyaret yapısını inşa ettirir. Amacımız, bu iki yapının mimari özelliklerini ve zaman içinde geçirdikleri değişimleri incelemek değildir (Richmond 1924; Creswell 1924; Creswell 1929; Diez 1934; Hamilton 1949; Goitein 1950; Grabar 1959; Stern 1963; Ülgen 1963; RosenAyalon 1975; The Architecture of Islamic Jerusalem 1976; Grabar 1980; Chen 1980-1981; al-Asalî 1982; Rosen-Ayalon 1989; Aslanapa 1989; Rosen-Ayalon 1996). Ancak, Kubbet el-Sahra'nın erken dönem Hıristiyan mimarisindeki merkezi planlı ziyaret yapılarından esinlenerek tasarlanmış ve Bizans üslubunda mozaiklerle bezenmiş bir Emevî yapısı olduğunu; Mescid el-Aksa'nın bugünkü yapısının ise Hz. Ömer tarafından yaptırılan ilk cami ile ilgisi olmadığını, hemen bütünüyle Eyyubî döneminde şekillendiğini, bu döneme ait bütün yapılar gibi, Haçlıların Batı'dan getirdiği gotik üsluptan alınmış bir takım mimarî ayrıntılar (ayrıca Haçlı dönemine ait devşirme parçalar) içerdiğini; Memlük, Osmanlı ve İngiliz Mandası dönemlerinde önemli onarımlar geçirdiğini belirtmekle yetinelim.

Harem-i Şerif'teki bu dirilişin, dinsel, siyasal ve kültürel nedenleri vardı: Mescid el-Aksâ ile Kubbet el-Sahra, her şeyden önce, İslâm'ın Hz. İbrahim geleneğine bağlılığını ifade etmekteydi. Hz. Ömer'in kutsal alanda yaptırdı ̆̆ camiye, Süleyman Tapınağı'nın Kur'an'daki adı olan "Mescid el-Aksâ" adının verilmesi bu bağlamda dikkate değer. Başka bir deyişle, mimarlık tarihindeki kopukluğa karşın Süleyman Tapınağı, anlam düzleminde - ancak bu kez islâmî bir çerçeve içinde- canlandırılmış olmaktaydı (Neuwirth 1996; Hasson 1996).

Kudüs, başkentleri Şam'a olan yakınlığından ötürü, başından beri
Emevîler için “alternatif” bir hac merkezi olarak görülmüş, bu yönde önemi vurgulanmıştır(3) (Buhl 1940, 956). Nitekim, Kubbet el-Sahra'nın inşa edildiği yıllarda, İbn Zübeyr Mekke'de kendisini halife ilan etmiş bulunuyordu. Abdülmelik de, Kubbet el-Sahra'yı inşa ettirdikten sonra egemenliği altında bulunan ve Emevî başkenti Şam'a yakın olan Kudüs'ü Mekke'nin yerine geçirmek niyetindeydi(4) (Buhl 1940, 957; Sharon 1973, 22). Ayrica söz konusu yapı, Yahudilerin ve Hiristiyanların kutsal kentinde İslâm egemenliğinin simgesiydi. Kudüslü ünlü coğrafyacı El-Mukaddesî (ö. 985/86), Kubbet el-Sahra'nın yapılış sebepleri arasında, Halife Abdülmelik'in, Kudüs'teki görkemli Hıristiyan makamlarını ziyaret eden ve bunlardan etkilenen Müslümanların dikkatlerini, kendi dinlerine bağlı ve diğerlerinden çok daha görkemli bir yapıya çekmek arzusunu da zikreder(5) (Buhl 1940, 956).

Emevîleri (661-750) izleyen Abbasî (750-868), Tolunoğlu (868-905), Fatımî (905-1070, 1096-1099) ve Selçuklu (1070-1096) Dönemleri boyunca Mescid el-Aksâ ile Kubbet el-Sahra'da sürekli bir onarım, tadilat ve yeniden inşa faaliyeti yaşandı. Haçlılar'ın kurduğu Kudüs Krallığı'nın egemenliği boyunca (1099-1187) Harem-i Şerif'in kutsallığ 1 Hıristiyanlığın kalıpları içinde sürdürüldü: Kubbet el-Sahra "Templum Domini" adıyla kiliseye çevrilmiş, "Templum Salomonis" ya da "Palatium Salomonis" olarak anılan Mescid el-Aksâ ise önce Kudüs Krallarının Sarayı, sonra Templier Şövalyeleri'nin yönetim merkezi olarak kullanılmıştı (Buhl 1940, 959; Sharon 1973, 2425; Bahat, 1976, 33-34; Burgoyne, 1987, 47; The New Encyclopedia..., 788). 

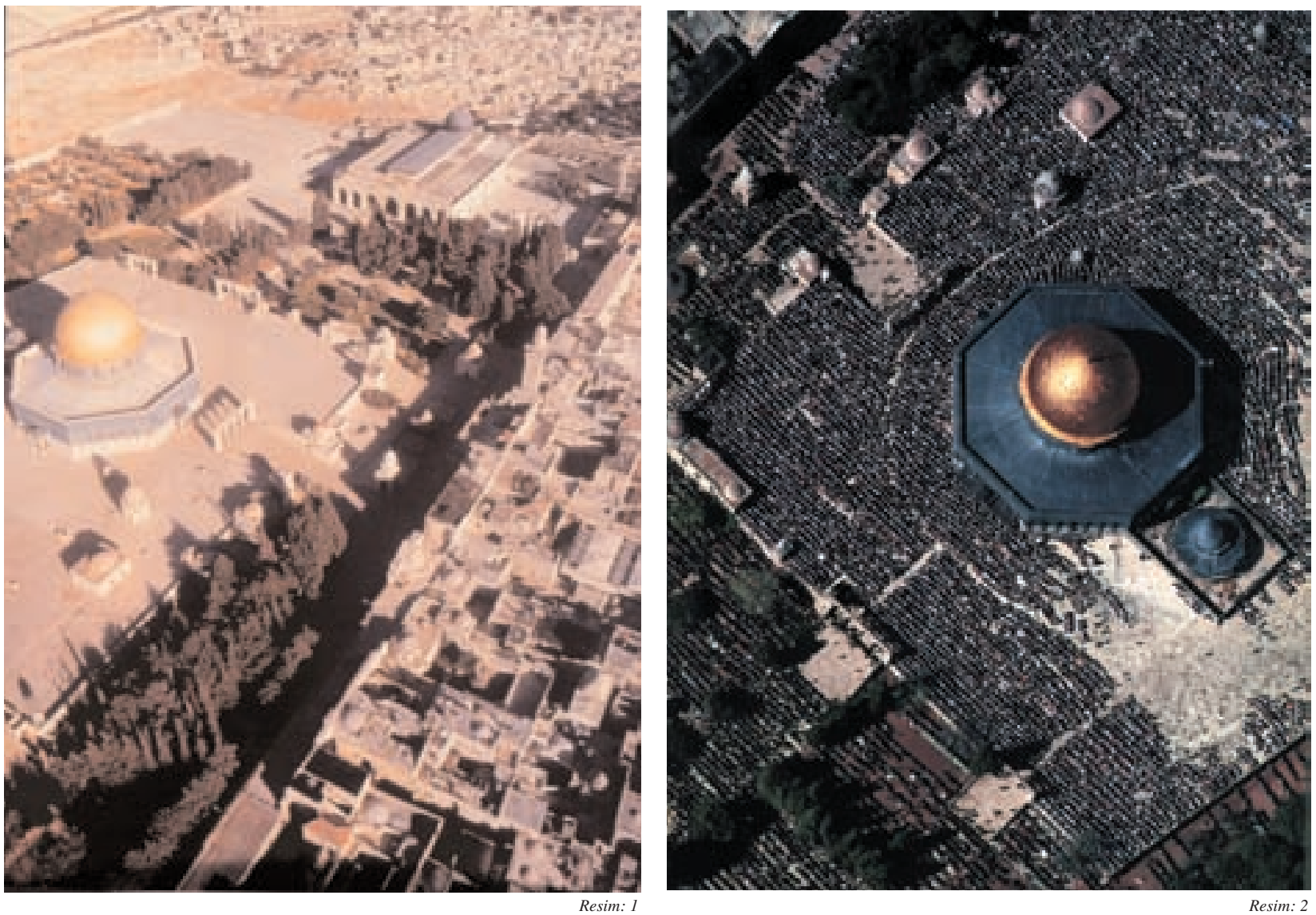

Kudüs'ün Salâhaddin Eyyubî tarafından 1187'de Haçlılar'dan geri alınmasıyla başlayan Eyyubî egemenliği (1187-1250), Harem-i Şerif için İslâm'a dönüş ve yeniden yapılanma dönemi oldu. Eyyubîler'i izleyen Memlûk (1250-1517) (Burgoyne 1979; Jarrar 1996) ve Osmanlı (1517-1917) dönemlerinde de, onarım faaliyetleri kesintisiz sürmüş; kutsal alanın kuzey ve batı kesimleri; medrese, ribat, hankah, mescit, makam, namazgâh, sebil, çeşme türünden irili ufaklı yapılarla donatılmıştır (Resim 1).

\section{Harem-i Şerif'in Kent Kimliğindeki Egemenliği}

Harem-i Şerif'in kent kimliği üzerindeki egemenliğini, sırayla iki boyutta: planda, üçüncü boyutta: siluette ve dördüncü boyutta: zaman boyutunda: toplumsal bellekte inceleyeceğiz.

\subsection{Iki Boyutta: Planda}

Kudüs'ün planına bakıldığında Harem-i Şerif'in iki boyuttaki egemenliği kolayca görülür. Kutsal alan, kentin yaklaşık 1/5'ini kaplamaktadır (Şekil 1). İçerdiği mimarî eserlerin yanı sıra geniş boşluklar içeren bu açık alanın dinginliği, kentin tümünde görülen karmaşı ve yoğun dokuyla tezat oluşturur. Nitekim, Mescid el-Aksâ'dan Kubbet el-Sahra'ya ve onun ötesine kadar uzanan kesim, cuma ve bayram namazlarında, iklim şartları elverdiği için, devâsâ bir açık hava camisine dönüşmektedir (Resim 2). Bu gelenek, kentte Harem-i Şerif'in dışında, birkaç küçük mescit hariç, neden hiçbir zaman cami inşa edilmediğini açıklar. İbadetin yanı sıra Harem-i Şerif' in çok önemli bir başka fonksiyonu ise ziyaretgâh olma özelliğidir.
Resim: I

Harem-i serif'in kuzey batıdan kuşbakışı görünümü (D. Tal - M. Haramati, Skyline Jerusalem, Bnei Brak 1999) Resim: 2 Harem-i serif'in toplu namaz sirasinda kuşbakışı görünümü (National Georaphic Magazine) 
Harem-i Şerif'in toplu ibadet ve ziyaret işlevlerini bünyesinde toplaması, İslâm döneminde konaklama, eğitim ve ticaret faaliyetlerini de yönlendirmiş; söz konusu fonksiyonları karşılayan yapılar, kutsal alanın kente açılan kuzey ve batı sınırlarında inşa edilmiş̧ir (Resim 1).

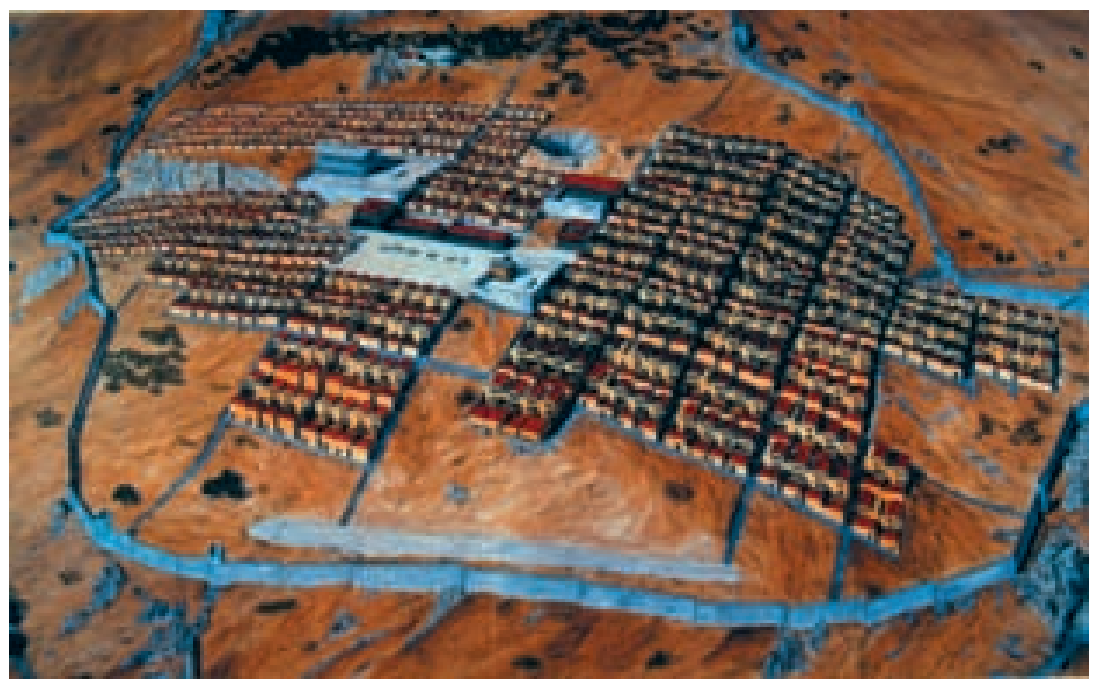

şekil: 2 Priene kentinin kuşbakışı restitüsyonunda agoranın konumu (W. Hoepfner E.-L. Schwander, Haus und Stadt im klassischen Griechenland. Neubearbeitung, München Berlin 1994).

Bunlar; ziyaretçilerin konakladığı ribatlar, Kur'an kıraatinin öğretildiği dârülkurralar, yüksek din eğitiminin verildiği medreseler, sufî etkinliklerinin yürütüldüğü ve seyyah dervişlerin konakladı $\breve{g}$ hankâhlardır. Ayrıca Harem-i Şerif'in varlığ 1 , bat1 yönünde sıralanan ve çarş1 bölgesine açılan kapılar aracılığıyla, kentteki ticaret hayatını ve bunun doğurduğu mimarî dokuyu kutsal alana doğru “çekmiştir”. Kudüs'ün başlica ticaret yapısı olan Sûk el-Kattanîn'in (Pamukçular Çarşısı) Harem-i Şerif'i, kentin en eski ve en canlı ticaret ekseni olan El-Vad Sokağı'na birleştirmesi bu hususu doğrular. Birbirine eklemlenerek Harem-i Şerif'i kuzey ve batı yönlerinden kalın bir duvar gibi kuşatan bu yapıların hemen hepsi, kentte yoğun bir imar faaliyetinin yaşandığı Memlûk Dönemi’ne (1250-1517) aittir.
Öte yandan, Harem-i Şerif'in kuzeybatı köşesinde Herodlar Dönemi'ndeki Antonia kale-sarayının temelleri üzerinde, Memlûk Dönemi'nde 1315-1320 arasında inşa ettirilen Câviliyye Medresesi, XV. yüzyılın ilk çeyreğinde tadil edilerek, valilerin makamı haline getirilmiştir. Bundan böyle kaynaklarda "Dâr elNiyâba" (Sultan'ın nâibinin makamı) olarak anılan yapı, Osmanlı Dönemi’nde de 1870 'lere kadar bu işlevini sürdürmüştür. Yönetim merkezindeki bu süreklilik, doğal bir kaya üzerinde yer alan bu mevki, Harem-i Şerif'e egemen konumuyla açıklanabilir. Başka bir deyişle, Harem-i Şerif'in varlığ kent yönetim merkezinin konumunu da belirlemiştir. İbadet ve ziyaret eylemlerinin yanı sıra Harem-i Şerif, kentte yaşayan Müslümanların gündelik hayatlarında çok önemli bir yer tutar. Sabah namazından önce açılan, yatsı namazından sonra kapatılan kutsal alanda, bu süre zarfında; ibadet saatlerinin dışında, revakların altında, ağaçların gölgesinde, namazgâhların ve zemini yükseltilmiş sofaların üzerinde, sohbet eden, okuyan, karnını doyuran, ya da uyuyan birçok insana rastlanır. Hatta bu eylemlere Mescid el-Aksâ'nın içinde de tanık olmak mümkündür.

Harem-i Şerif, gerek ibadet, ziyaret ve yönetim işlevlerini bünyesinde toplamasıyla, gerekse gündelik hayatın odağı olmasıyla; Antik Yunan'daki agoralar (örneğin Batı Anadolu'da Priene kentinin agorası) (Şekil 2), Roma'daki forumlar, Ortaçağ' daki meydanlarla kıyaslanabilir. Ancak, bölgedeki Samî kültürlere (Aramî, İbranî, Arap, vd.) özgü "harem" kavramından dolayı, duvarlarla kentten soyutlanmasıly agoraforum-meydan geleneğinden ayrılır. 


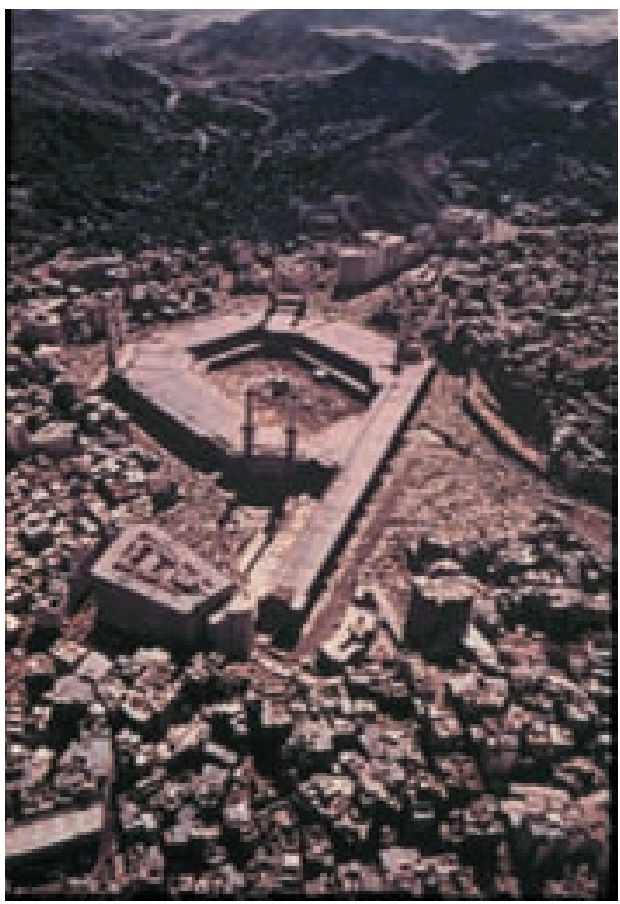

Resim: 3

Bu yönüyle Harem-i Şerif, kökeni aynı tektanrılı geleneğe (İbrahimî geleneğine) bağlanan Kâbe'ye benzetilebilir (Resim 3). Kâbe'nin Arap geleneğinde "Mescid el-Haram" veya "Harem-i Şerif" olarak anılması bu bakımdan dikkate değer.

\section{2. Üçünü Boyutta: Siluette}

Karmaşık bir dokuya sahip olan Kudüs'ün engebeli topografyası üzerinde sıralanan kubbeler, minareler ve çan kuleleri son derece hareketli bir siluet çizerler. Bu hareketli siluetin içerisinde Harem-i Şerif, çevrenin en yüksek tepelerinden biri üzerinde yer almasıyla, üçüncü boyutta da kente egemen olmaktadır. Harem-i Şerif'teki iki önemli yapıdan Kubbet elSahra, gerek konumu, gerekse de tasarımıyla güçlü bir görsel odak teşkil eder. Nitekim, söz konusu yapı kutsal alanın kuzey kesiminde yer alan ve zemini yükseltilmiş bir plato üzerinde bulunmaktadır. Ayrıca, Kubbet el-Sahra'nın merkezî planlı kitlesi ve bunu taçlandıran yüksek kasnağı ve soğan kubbesi, yapının görsel etkisini güçlendirdiği gibi, onu kentin her noktasından görünür kılmaktadır. Buna

karşılık, kutsal alanının güney sınırında, kotu düşük bir terasta yer alan Mescid elAksa, yayvan kitlesiyle onun kadar dikkat çekmez (Şekil 3). Sonuçta, Harem-i Şerif' in kent kimliği üzerindeki egemenliğini üçüncü boyutta daha çok Kubbet el-Sahra temsil eder.

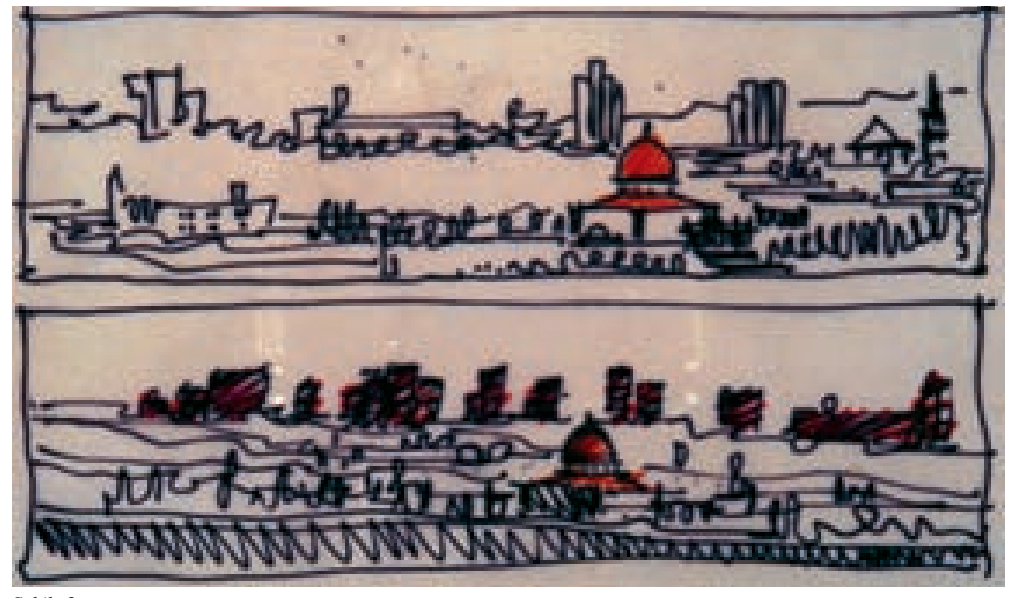
Şekil: 3

\subsection{Görsel ve Toplumsal Bellekte}

Bir önceki paragrafın sonunda değinilen husus Kudüs'e ilişkin görsel belleğin oluşumunda da geçerliliğini korur. Kubbet el-Sahra, çağglar boyunca Doğu'da olduğu gibi Batı'da da görsel bellekte Kudüs imgesinin en belirgin öğesi olmuştur. Nitekim, Avrupa resim sanatında ayrıca mimarî eserlerin gösterildiği panoramik haritalarda binlerce Kubbet el-Sahra tasviri üretilmiştir (Behrouzı 1993; Gonen 1994; Fishof-Bar'am-Ben Yossef 1996; Levy-Rubin Rubin 1996; Rosovsky 1996; Bahat - Sabar 1997; Kühnel 1998; Rubin 1999). Kudüs’ü gösteren manzara resimlerinin ve panoramik haritaların büyük çoğunluğunda, merkezde Kubbet el-Sahra yer alır. Ortaçağ'dan XVIII. yüzyıla uzanan döneme ait örneklerin çoğunda, kulaktan dolma bilgilere dayanılarak üretildiği anlaşılan Kubbet elSahra tasviri, ne oranları ne de çevresiyle gerçeği yansıtır. Üstelik, bu tasvirlerin çoğunda Kubet el-Sahra Süleyman Tapınağı olarak algılanmaktadır. Örneğin, Sebald Rieter'in 1475 civarına tarihlenen
Resim: 3 Kâbe'nin kuşbakışı görünümü (National Geographic Magazine, 154/5, 1978).

şekil: 3

Kent siluetinde Kubbet elsahra'nin konumu (A. Kutcher 1973, The New Jerusalem, Planning and Politics, London) 'ten K. Türkantoz'un yorumu)

şekil: 4

Sebald Rieter'in 1475 civarina tarihlenen Kudüs haritası ( $M$. Levy-Rubin - R. Rubin 1996, "The Image of the Holy City in Maps and Mapping", City of the Great King - Jerusalem from David to the Present, ed. N. Rosousky, Cambridge Mass, London, 352-379) Resim: 8

Hartmann Schedel'in 1493'te

Nürnberg'de basilan Liber Chronicarum'undaki Kudüs görünümü (B. Kühnel 1998, "Introduction - The Use and Abuse of Jerusalem", The Real and Ideal - Jerusalem in Jewish,

Christian and Islamic Art,

Studies in Honor of Bezalel Narkiss on the Occasion of his Seventieth Birthday, Jewish Art, Vol. XXIII-XXIV, 1997/98, ed. B. Kühnel, Jerusalem, XIX-XXXVIII) 


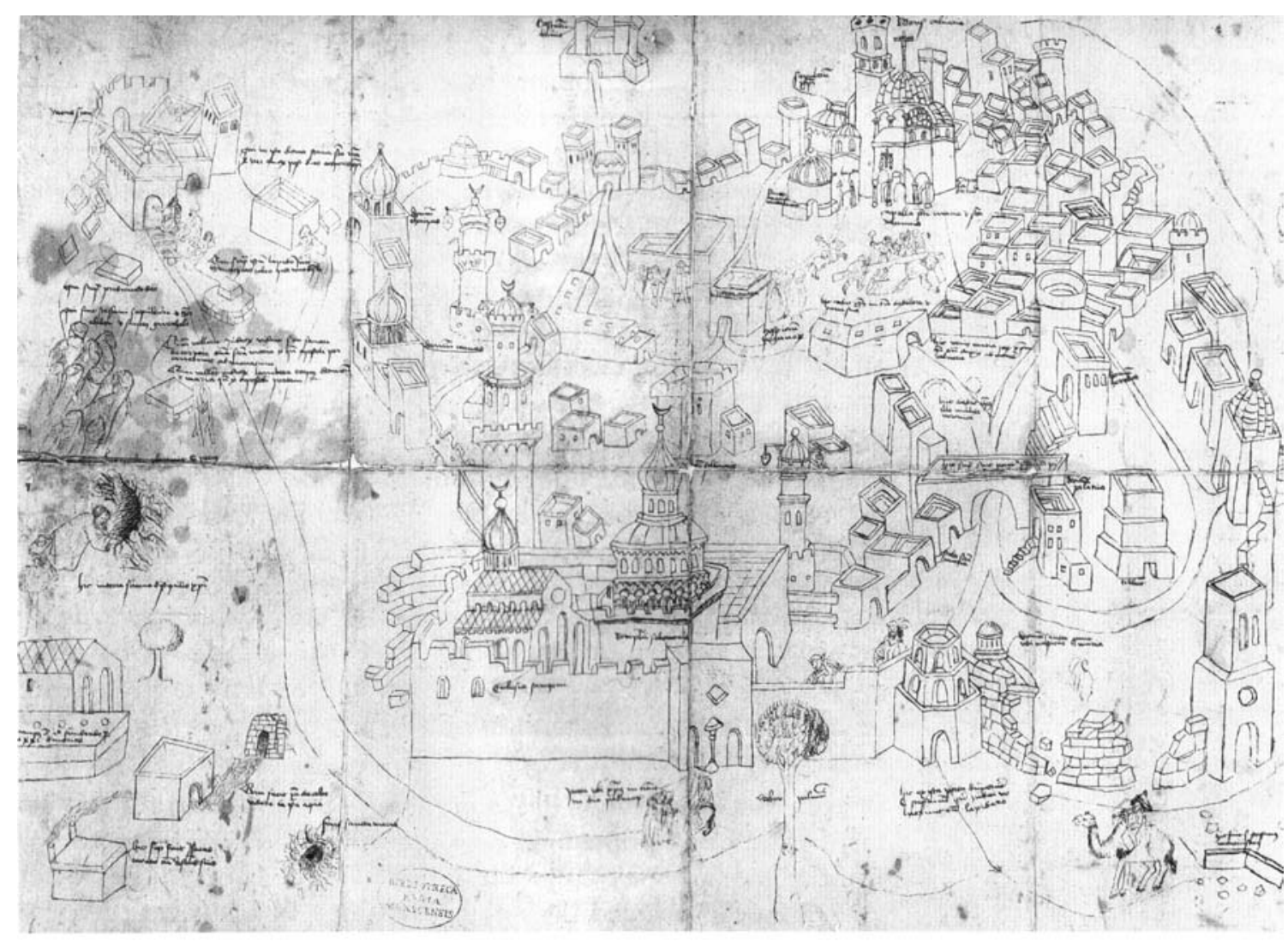

Şekil: 4

Kudüs haritasında, soğan kubbeli (!) olarak tasvir edilen Kubbet el-Sahra, hilâl biçimindeki alemine rağmen (!)

"Templum Salomonis" olarak adlandırılmıştır (Rubin 1999, 364-365, fig.42), (Şekil 4).

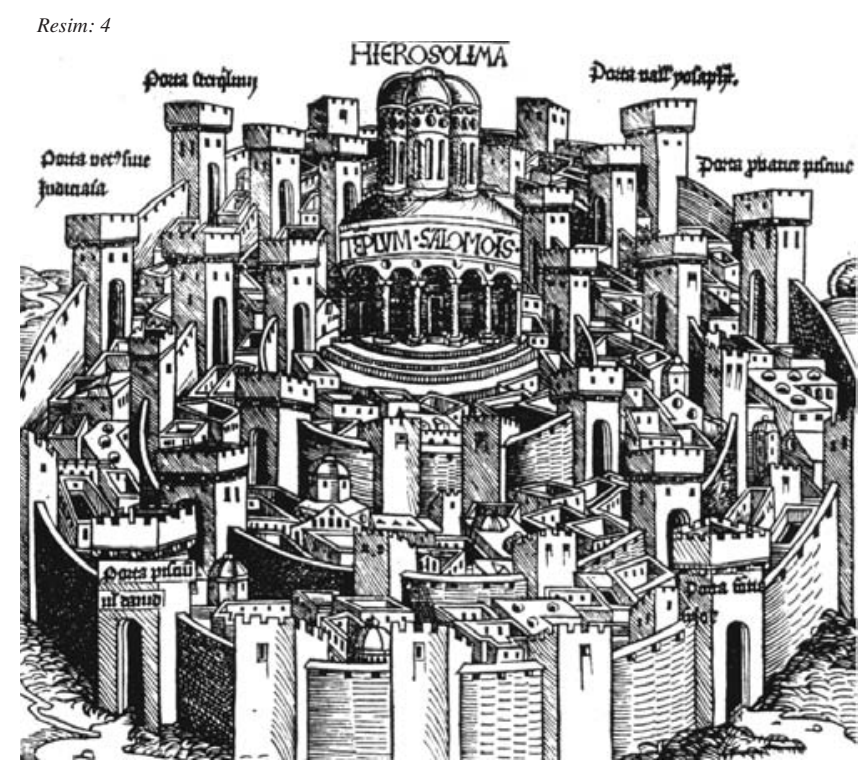

Öte yandan Hartmann Schedel'in 1493 'te Nürnberg'de basılan Liber Chronicarum'undaki Kudüs görünümünde, kentin merkezinde yükselen, merkezi tasarımı ve kubbesiyle Kubet el-Sahra'dan esinlenmiş olduğu göze çarpan yapı da Templum Salomonis'tir (Kühnel 1998, XXVII, fig.7), (Resim 4).

Aynı şekilde, Tevrat ve İncil'deki olayları tasvir eden Röneans sanatçıları, Kubbet el-Sahra'yı çoğu kez Süleyman Tapınağı için bir model olarak görmüşlerdir. Örneğin, İtalyan ressamlarından Perugino'nun (yaklaşık 1472-1523 arasında faal), Vatikan Sistin Şapeli'nde bulunan ve Hz. İsa'nın Aziz Petrus'a anahtarları teslim edişini gösteren 1481 tarihli freskosunda (Resim 5), fondaki Süleyman Tapınağı, sekizgen piramit biçimindeki gövdesi, merkezî kubbesi ve dört yöne açılan girişleriyle Kubbet 
el-Sahra'yı hatırlatır (Bahat-Sabar 1997, 84). Ne var ki, yapının oranları, cephe düzenlemesi, girişleri taçlandıran üçgen alınlıklar ve kubbenin dilimleri gibi birçok ayrıntı, ressamın yaşadığı Rönesans Dönemi'nin mimarî zevkini yansıtmaktadır. Özellikle tapınağın yanlarında, Harem-i Şerif'te, Kubbet el-Sahra'nın bulunduğu platforma geçit veren kemer

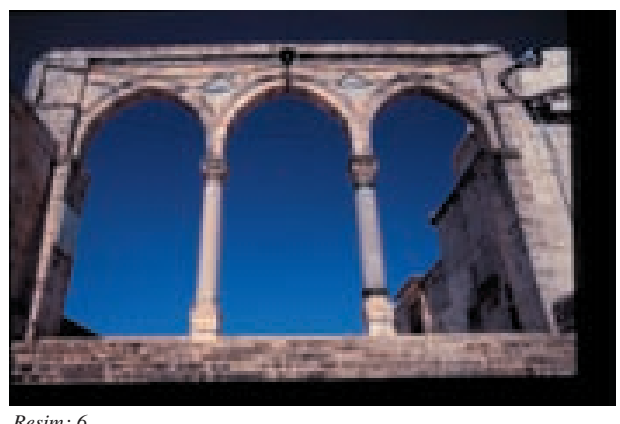

dizilerinden (kanâtirlerden) (Resim 6) esinlenerek yapıldı $\breve{g} 1$ anlaşılan anıtsal kapıların tamamen Roma üslubunda zafer takları biçimini almış olmaları dikkat çekicidir.

XVIII. yüzyıldan itibaren özellikle Doğu merakının (Oryantalizmin) geliştiği XIX. yüzyılda, sanatçıların bizzat Kudüs'te çalışarak kentin görünümünü ve Kubbet el-Sahra'yı, eski dönemlere oranla daha gerçekçi biçimde tasvir ettikleri gözlenir. Paul Wilhlem Keller-Reutlinger'in (18541920) Kubbet el-Sahra'yı gösteren boyalı taş baskısında, yapının sekizgen prizma biçimindeki altyapısı nispeten doğrudur. Ne var ki aşırı yükseltilmiş olan kubbe gerçeği yansitmaz (Gonen 1994, 12, fig.1), (Resim 7). Buna karşılık A. Graf von Wartesleben'in, Kudüs'ü kuşbakışı görünümünü sunan 1870 tarihli boyalı taş baskısında, Harem-i Şerif'in ve özellikle Kubbet el-Sahra'nın fotoğrafik bir gerçeklikle tasvir edildiği dikkati çeker (Rubin 1999, 169, fig.106), (Resim 8). Öte yandan dinsel akımların güçlendiği ve Kudüs

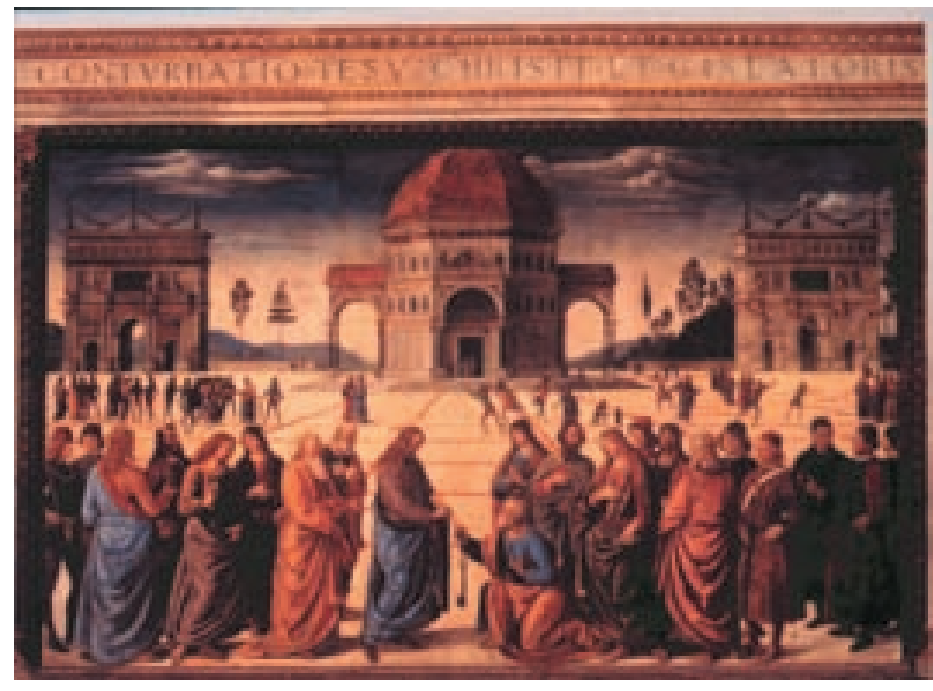

Resim: 5

imgesinin önem kazandığı XIX. yüzyıl

Amerika'sında üretilmiş olan Kudüs

panoramalarında da, Kubbet el-Sahra'nın görsel egemenliği sürmektedir. Amerikalı oryantalistlerden James Fairman'ın (18261904), gün batımında Zeytin Dağı'ndan Kudüs'ün görünümünü betimleyen tablo örnek olarak sunulabilir (Ackerman 1994, 7681), (Resim 9).

Resim: 5 Perugino'nun (1472-1523 arasinda faal), Vatikan sistin şapeli'nde bulunan ve Hz. Isa'nın Aziz Petrus'a anahtarları teslim edişini gösteren 1481 tarihli freskosu (D. Bahat

- S. Sabar, Jerusalem stone and Spirit - 3000 Years of History and Art, Jerusalem 1997).

Resim: 6

Bunların yanı sıra, Kudüs'e giden Hıristiyan ve Musevî hacıları için üretilmiş, halk sanatının kapsamına giren hediyelik Harem-i serif'te, Kubbet el-sahra platformunun güneybatısındaki kanâtir (Tanman 1999). eşyalarda da Kubbet el-Sahra'nın temsilî gücü kendini gösterir(Rosovsky 1996, 344-351).

Resim: 7

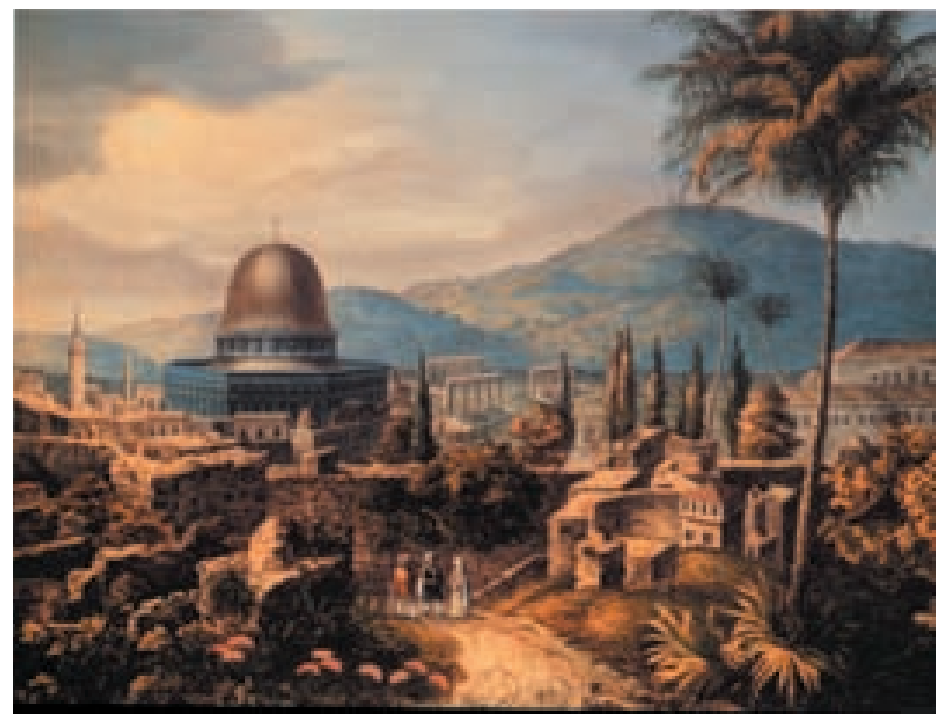




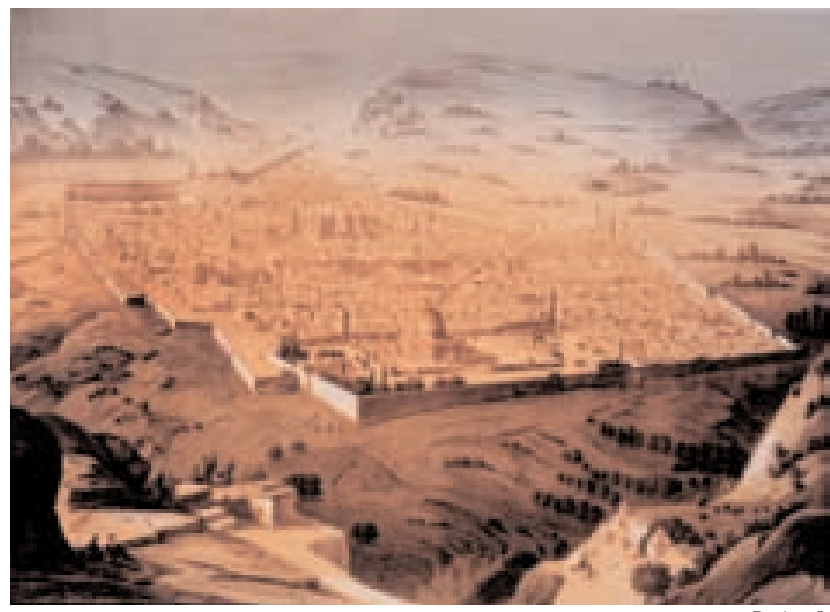

Resim: 8

Resim: 7

Paul Wilhelm KellerReutlinger'in (1854-1920) Kubbet el-sahra'yı konu alan boyalı taş baskısı, viyana (Gonen 1994, Jerusalem Yesterday and Today, Jerusalem).

Resim: 8

A. Graf von

Wartensleben'in, Berlin'de 1870'de basılmış, Kudüs'ü kuşbakışı tasvir eden boyalı taş baskısı (Rubin 1999, Image and Reality. Jerusalem in Maps and views, Jerusalem).

Resim: 9

James Fairman'in (18261904), Kudüs'ün Zeytin Dağı'ndan görünümünü betimleyen tablosu (Ackerman 1994, American Orientalists).

\section{Resim: 10}

Cam üzerine yağlıboya ve gümüş varağıyla yapılmıs süleyman Tapınağı tasviri, XX. yüzyıl, Kudüs israil Müzesi (I. Fishof N. Bar'am-Ben Yossef 1996, Souvenirs aus dem Heiligen Land für Pilger im 19 und 20 Jahrhundert - souvenirs de Terre sainte pour les pèlerins du XIXe siècle, Jerusalem).

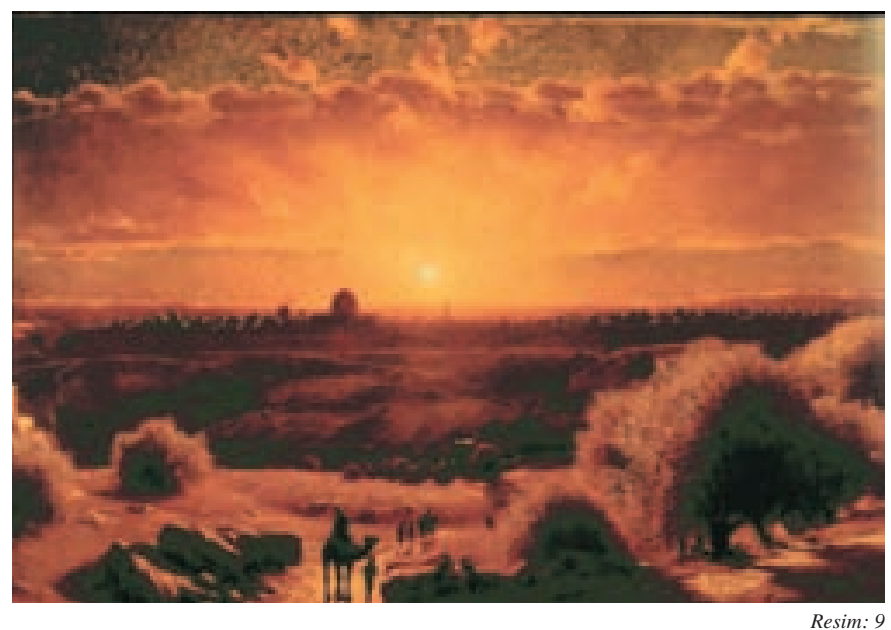

Kudüs, söz konusu olduğunda, Harem-i Şerif'in merkezindeki Kubbet el-Sahra, tarihsel ve mimarî bağlamından çoğu kez soyutlanmış olsa da tek başına kutsal kentin simgesi olmuştur. Hatta, söz konusu yapı giderek kentin "amblemi" olarak tanımlanmaya başlamış ve günümüzün deyimiyle- "inanç turizminin" odağ1 olan bütün kentlerde gözlemlendiği gibi "turistik objeye" dönüşmüştür. Ancak bu "simge -amblem -turistik obje" dönüşümünün Kubbet el-Sahra'nın, Kudüs'ü "simgelediğì" gerçeğini ortadan kaldırmadığ sürülebilir 1

\section{Simgenin Ambleme ve Turistik Objeye Dönüşümü}

Pek az kentte, kimliğin belirli bir öğeyle bu denli bağlantılı olduğu gözlenir.

Örneğin, İstanbul'da, Ayasofya, Sultan Ahmet Camii, Galata Kulesi, Kız Kulesi, vb. bir çok "simge yapının" (Arık 1976; Renda 1977; Okçuoğlu 2000) varlığına karşılık 
KAYNAKÇA

Ackerman, G. M.1976. American Orientalists, Paris 1994. The Architecture of Islamic Jerusalem, Jerusalem .

Arık, R. 1976. Batılılașma Dönemi Anadolu Tasvir Sanatı, Ankara

Alasali, K. C. 1982. Min âthârinâ fî Bayt al-Maqdis, Amman Aslanapa, O. 1989. "Kubbet el-Sahra'da Osmanlı Devri Tamirleri”, Sanat Tarihinde Doğudan Batıya Ünsal Yücel Anısina Sempozyum Bildirileri, İstanbul 15-18.

Bahat, D. 1976. Carta's Historical Atlas of Jerusalem. A Brief Illustraded Survey, Jerusalem (2.basim).

Bahat, D. 1996. "The Physical Infrastructure", The History of Jerusalem - the Early Muslim Period (638-1099), ed. Joshua Ben-Shammai, New York , 38 100.

Bahat, D.- S. Sabar 1997. Jerusalem Stone and Spirit. 3000 Years of History and Art, Jerusalem

Behrouzi, N. 1993. Jerusalem - Spirit and Matter, Tel Aviv Buhl, F. 1940. "Kudüs", İslâm Ansiklopedisi, VI, 952-964.

Burgoyne, M. H. 1979. The Development of the Haram in Jerusalem under the Bahri Mamluks, yayınlan mamış tez, Oxford

Burgoyne, M. H. 1987. Mamluk Jerusalem, an Architectural Study, Jerusalem

Chen, D. 1980-1981 "The Design of the Dome of the Rock in Jerusalem", Palestine Exploration Quarterly, 41-50.

Creswell, K. A. C. 1924. The Origin of the Plan of the Dome of the Rock, London

Creswell, K. A. C. 1929. "La Mosquée Al Aqsâ et la Néa de Justinien”, Byzantion, IV, 301-311.

Dan, J. 1996. "Jerusalem in Jewish Spritiulity", City of the Great King - Jerusalem from David to the Present, ed. N. Rosovsky, Cambridge Mass. London 60-73.

Diez, E. 1934. "The Mosaics of the Dome of the Rock at Jerusalem", Ars Islamica, I, 235-238.

Fishof, I.- N. Bar'am-Ben Yossef 1996. Souvenirs aus dem Heiligen Land für Pilger im 19 und 20 Jahrhundert / Souvenirs de Terre Sainte pour les Pèlerins du XIXe siècle, Jerusalem

Fredrisken, P.1996. "The Holy City in Christian Thought", City of the Great King - Jerusalem from David to the Present, ed. N. Rosovsky, Cambridge Mass. London

GiL, M. 1996. "The Political History of Jerusalem During the Early Muslim Period", The History of Jerusalem The Early Muslim Period (638-1099), ed. J. BenShammai, New York 1-37.

Goitein, S. D. 1950. "The Historical Background of the Erection of the Dome of the Rock. Brief Communication", Journal of the American Society, LXX, 104-108.

Gonen, R. 1994. Jerusalem Yesterday and Today, Jerusalem Grabar, O. 1959. "The Umayyad Dome of the Rock in Jerusalem", Ars Orientalis, III, 33-62.

Grabar, O. 1980 "Kubbat al-Sakhra" ve "al-Kuds. Monuments", Enc. Islam, new ed., 5, 298-299, 339-344.

Hamilton R. W. 1949. The Structural History of the Aqsa Mosque. A Record of Archaeological Gleanings from the Repairs of 1938-1942, Oxford

Hasson, I. 1996. "The Muslim View of Jerusalem - the Qur'an and Hadith", The History of Jerusalem - The
Early Muslim Period (638-1099), ed. J. BenShammai, New York, 349-385.

Jarrar, S. 1996. "Two Islamic Construction Plans for al-Haram al-Sharif', City of the Great King - Jerusalem from David to the Present, ed. N. Rosovsky, Cambridge Mass. - London, 380-416.

Kühnel, B. 1996. "Geography and Geometry of Jerusalem", City of the Great King - Jerusalem from David to the Present, ed. N. Rosovsky, Cambridge Mass. London, 288-332.

Kühnel, B., 1997-1998 "Introduction - The Use and Abuse of Jerusalem", The Real and Ideal - Jerusalem in Jewish, Christian and Islamic Art, Studies in Honor of Bezalel Narkiss on the Occasion of his Seventieth Birthday, Jewish Art, Vol. XXIIIXXIV, ed. B. Kühnel, Jerusalem, XIX-XXXVIII.

Levy-Rubin, M. R.1996. "The Image of the Holy City in Maps and Mapping", City of the Great King Jerusalem from David to the Present, ed. N Rosovsky, Cambridge Mass. - London, 352-379.

Neuwirth A. 1996. "The Spiritual Meaning of Jerusalem in Islam”, City of the Great King - Jerusalem from David to the Present, ed. N. Rosovsky, Cambridge Mass. - London

The New Encyclopedia of Archaeological Excavations in the Holy Land, Israel 1993.

Okçuoğlu, T. 2000. 18. ve 19. Yüzyıllarda Osmanlı Duvar Resimlerinde Betimleme Anlayışı, İstanbul Üniversitesi Sosyal Bilimler Enstitüsü, yayınlanmamış doktora tezi

Renda G. 1977. Batılılașma Döneminde Türk Resim Sanat 1700-1850, Ankara

Richmond, E. A. 1924. The Dome of the Rock in Jerusalem. A Description of its Structure and Decoration, Oxford

Rosen-Ayalon, M. 1975. "The Islamic Architecture of Jerusalem”, Jerusalem Revealed, Jerusalem, 92-96.

Rosen-Ayalon, M. 1989. The Early Islamic Monuments of Haram al-Sharîf: an Iconographic Study, Jerusalem

Rosen-Ayalon, M. 1996. "Art and Architecture in Jerusalem in the Early Islamic Period", The History of Jerusalem - The Early Muslim Period (6381099), ed. J. Ben-Shammai, New York, 386-412.

Rosovsky, N. 1996. "The City in Jewish Folk Art", City of the Great King - Jerusalem from David to the Present, ed. N. Rosovsky, Cambridge Mass. London, 344-351.

Rubin, R. 1999. Image and Reality. Jerusalem in Maps and Views, Jerusalem

Sharon, A. 1973. Planning Jerusalem, The Old city and its Environs, Tel Aviv

Stern, H. 1963. "Recherches sur la Mosqueé al-Aqsâ et sur ses Mosaïques", Ars Orientalis, V, 27-47.

Ülgen, A. S. 1963. "Kudüs’te Harem-i Serif Dahilindeki Kubbetü's-Sahra (E's-Sahratü'l-MüşerrefeCami-i Ömer) in XVI.Yüzyılda Yapılmıs Olan

Çinileri”, Türk San'atı Tarihi Araştırma ve Incelemeleri, I, İstanbul, 657-676. 